\title{
French propose agency to spur European defence research
}

Paris. The French minister of defence, Pierre Joxe, has called for the creation of a European Armaments Agency (EAA) to coordinate big-science projects in military research. Speaking last week at the close of a two-day conference entitled "Science and Defence: New Europe, New Research", Joxe also announced research collaborations with the Commonwealth of Independent States, the creation of a French version of the Massachusetts Institute of Technology (MIT) and new ways to integrate French defence and civilian research programmes.

European countries already cooperate in military research. In 1989,13 of them launched the EUCLID (EUropean Cooperation for the Long term In Defence) programme to foster multinational cooperation in fundamental research. The programme supports work in areas related to simulation, microelectronics, acoustics and radar, robotics and artificial intelligence. But decisions about who will participate, and how much each government will contribute, have slowed progress, and it will be several more weeks before the first contracts are announced.

No details are available on how the EAA would operate beyond that it would be modelled after the European Space Agency. Joxe imagines that it would begin by assum- ing management of EUCLID and other multilateral research agreements.

One example of the type of research that could be carried out under EAA is a proposed telecommunications satellite programme. The French Syracuse II telecommunications satellite is a joint venture between the Ministry of Defence and France Telecom. But the rising cost of such satellites has already led to discussions of cooperative efforts by a newly formed group, EUMILSATCOM, that represents Britain, France, German, Belgium and the Netherlands.

French officials insist that the EAA poses no threat to the national security of individual countries. "As the interests of each country become more common, they will share secrets", says Jacques Lanxade, the army's chief of staff. "France is ready to share." Joxe says that 90 per cent of French military research, excluding nuclear weapons, is already in the public domain.

The new armaments agency would not prevent research agreements between individual nations. France has made an initial investment of FF50 million (US $\$ 10$ million) towards research cooperation with the countries of the former Soviet Union, and defence officials have begun to evaluate the capabilities of laboratories in those coun- tries with a view to joint research, licensing, scientific exchanges and subcontracting.

Internally, France hopes to take advantage of whatever 'peace dividend' exists to increase research spending in such areas as biomedicine, space, information technology and communications, acoustics and robotics. This year's defence research budget will nearly double funding for space research, to FF450 million, and will significantly increase support for research in public laboratories and universities. It comes at a time when almost every other part of the military budget is being slashed.

Joxe and Hubert Curien, minister for research and space, say that they want to "tighten the links between civil and defence research". To that end, the two are considering a centre to develop and test advanced robots with dual uses, and an announcement is expected soon that will add military objectives to the role of the space research agency Centre National d'Etudes Spatiales.

The hub of France's proposed version of MIT will be the Ecole Polytechnique at Palaiseau near Paris. One of the oldest and most renowned of the Grand Ecoles, the polytechnique trains engineers and scientists for the nation's high-technology companies. A science and technology pôle (centre of excellence) (see Nature 356, 373; 1992) will be formed at the site, bringing together the Ecole National Supérieure des Techniques Avancées, the government's weapons laboratories, the army documentation centre and a proposed technology transfer centre to be called $X$-pôle.

David Bakewell

\section{Swiss vote for biotechnology, with controls}

Basel. Switzerland's first law regulating reproductive medicine and biotechnology has been written into the statute following its approval by 74 per cent of the population in last weekend's plebiscite. The law provides a framework for more detailed regulations, and pressure groups are already campaigning for tighter controls on biotechnology that could have severe consequences for Switzerland's drug companies.

In Switzerland, any proposal to introduce new legislation must be taken to a public vote if it gains at least 100,000 signatures. The government has the right to put forward a counter-proposal. Either measure becomes law if it receives a majority vote.

Prompted by the absence of any specific legal control of genetic engineering, pressure groups led by the political magazine Der Beobachter collected 127,000 signatures in favour of a draft code in 1987. But they withdrew it after endorsing the government's counter-proposal.

It is this counter-proposal that passed on 18 May. Swiss scientists interpret the vote as a public endorsement of genetic engi- neering, subject to control. It defines clearly new regulations for reproductive medicine. In vitro fertilization and embryo transfer will be restricted. And the use of surrogate mothers, manipulation of embryos (for example, to determine sex) and the introduction of non-human genetic material into the human genome are expressly forbidden.

The new law is less clear about biotechnology, suggesting that the government should act "to ensure the dignity of organisms and the security of man, animal and environment". Bernhard Bühler, spokesman for the Swiss Society of Chemical Industries, says that this language conforms to the ethical guidelines laid down by the society two years ago.

But a different set of pressure groups, under the umbrella of the Swiss Working Group on Genetic Engineering (Schweitzischer Arbeitsgruppe Gentechnologie, SAG), are already campaigning for much stricter federal regulations. Twenty-three organizations, ranging from the World Wide Fund for Nature to the Association of Small Farmers, collected signatures in front of last
Sunday's polling booths. Their proposal would ban both the patenting and the release of genetically manipulated organisms, as well as the creation of mutant animals. And it promises very strict regulations, as yet undefined, on industry.

Basel's powerful anti-biotechnology lobby already influences the decisions of its local pharmaceutical giants. Last December, Ciba-Geigy withdrew its plan to build a large biotechnology centre in Basel; it is now being built $10 \mathrm{~km}$ away, in France, where the political climate is better and there are fewer bureaucratic obstacles. Drug companies are concerned that the situation would become even worse if the SAG manages to place its proposals on the ballot.

Paul Walter, president of the Swiss Academy of Science, says that it would be hard for industry to cope with the provisions of the SAG initiative. But he sees the large margin by which the compromise was accepted (support in Basel was 82 per cent) as a sign that Swiss voters are reluctant to do anything that would threaten the country's economic health.

Oliver Klafike 